\title{
THE EFFECTS OF MATERNAL BRUCELLOSIS ON PREGNANCY OUTCOME
}

\author{
Maged Elshamy, MD*\#, Osama M. Warda, MD*: Mostafa M. Elkhiary, MD*, and \\ Amien, $A I, P h D^{*: * \#}$ \\ * Department of Obstetrics and Gynecology, Faculty of Medicine, Mansoura University, Egypt. \\ ** Laboratory of Biochemistry, Faculty of Science, Cairo University, Egypt. \\ \# EL-Hasan National Hospital, EL-Rawad Clinic, Taif, Saudi Arabia
}

\section{ABSTRACT}

Objective: The aim of this study was to assess the outcome of pregnancies complicated by brucella infection.

Design : Prospective study

Setting : EL-Hasan National Hospital, El-Rawad Clinic, TAIF, SAUDI ARABIA (where the practical part of the study was accomplished), and Obstetrics \& Gynecology Department, Mansoura University Hospital (where the theoretical part of the study was completed).

Methods: This study was carried out from August 2004 to December 2005. Tube method for detection of antibedy titre for brucellosis was done to 450 pregnant females (415 have no symptoms or signs of brucellosis and 35 have symptoms and signs for the disease).The antibody titre was positive in 55 Pregnant females (group 1) and negative in 395 pregnant females (group 2). Both groups were followed up during pregnancy and neonatal period to determine any type of reproductive failure.

Results: The incidence of brucellosis was $12.2 \%$ in all tested pregnant females. The incidence of abortion in group । was $27.27 \%$, IUFD was $12.72 \%$ and preterm labour was $10.90 \%$. There was a statistically signilicant difference as regards abortion and IUFD in both tested groups. There was a statistically signilicant difference as regards abortion in patients having a titre more than $1 / 160$ compared to those who have a lower titre.

Conclusion: The frequency of fetal loss among patients with brucellosis is very high. It is advisable to have a high degree of alertness for brucellosis in endemic areas.

Key worts : Brucellosis, brucella, abortion, IUFD, preterm labour

\section{INTRODUCTION}

Brucella specics are facultative intracellular pathogens that have the ability to survive and multiply in professional and non professional phagocytes and cause undulant fever in humans (1). Several species are recognised within the genus brucella. The bacterium possesses an unconventional non endotoxic lipopolysaccharide that confers resistance to antimicrobial attacks and modulate the host immune response ${ }^{(2)}$. Brucella is a coccobacillus, gram negative bacterium, non sporing, non motile aerobic, whose hosts are mostly animals ${ }^{(3-4)}$ and has four species abortus, canis, melitensis and Suis (5). Brucellosis is a major zoonotic diseasc. Control of brucellosis in agricultural animals is a prerequisite for the prevention of the disease in human beings (6).

The interest of brucella as a biological weapon resides in the fact that transmission through a spray is possible as has been reported with human contamination during abortion of infected animals or bacterial spraying in laboratorics. It is suggested that 10-100 bacteria would be sufficient to produce a

Corresponding author : Osama M. Warda, MD; Obstetrics \& Gynecology Department- Mansoura University Teaching Hospital- ElGomhorrea street -Mansoura- EGYPT, e-mail : om2warda@yahoo.com, osamawarda@ mans.edu.eg 
contaminating spray for humans (7). Farmers, meat processing workers, veterinarian and laboratory workers are at risk (5). Human to human transmission is uncommon and has been described after blood transfusion (8), bone marrow transplantation (9) and possibly during sexual intercourse (10). Brucellosis is common in Mediterranean region, East Africa, Arabian Gulf region and endemic in Saudi Arabia (national prevalence, 15\%) (11). Endemicity in saudia Arabia results from the persistence of Domestic animal reservoirs for brucella species and the human consumption of unpasteurized products (12-13).

There is controversy about the relationship between brucellosis and the outcome of pregnancy (14). There are some evidences that there is a higher rate of complications such as abortion, preterm labour and IUFD more frequently than do other bacterial infections ${ }^{(14)}$. It is postulated that maternal bacteremia, toxemia, acute febrile reaction and DIC are causes of spontaneous abortion and IUFD in brucellosis ${ }^{(15)}$.

It is believed that brucellosis causes fewer spontaneous abortions in humans than it does in animals because of the absence of erythritol in the human placenta (16) which appears to be a preferentional medium and growth factor for brucella in the placenta of animals. An additional reason for the lesser role of brucella infection in human abortion is the presence of anti-brucclla activity in human amniotic fluid (17).

\section{MATERIALS \& METHODS}

This study was conducted on 55 pregnant women with positive brucella antibodies (group 1) and 395 matched pregnant controls ( group 2) at ELHASAN NATIONAL HOSPITAL and ELRAWAD CLINIC, Taif, Saudia Arabia from august 2004 to December 2005.

All cases were pregnant in the first trimester (first trimester up to 12 weeks; second trimester is from more than 12 weeks to $\leq 24$ weeks), fetal death that occurred less than 24 weeks gestation was considered spontaneous abortion while that occurring after 24 weeks gestation was designed 'intrauterine letal death'.

Diagnosis of brucella was done as follows: Fasting blood samples $(5 \mathrm{ml})$ were withdrawn from each subject in a clean dry tube, then kept at room temperature for 15 minutes to clot: serum was separated after centrifugation at $3000 \mathrm{rpm}$ for 10 minutes and the biochemical tests were carried out. Scrum antibody titre was evaluated by the method of freter (1980) (18). In our patients, positive brucella test was considered when the titre was more than $1 / 160^{(19)}$.

Exclusion criteria were subjects infected with toxoplasmosis, CMV, rubella, syphilis. $\mathrm{HCV}$. and diabetic females or presence of medical disorders. Serum toxoplasmosis, CMV, Rubella and HCV antibodies were determined using enzyme linked immunosorbent assay technique (ELIZA) according to the methods of Wisdom $(1976)^{(20)}$. Engvall and Perlmann (1971)(21), Vcheri and Salonen (1980)(22) and Alter et $\mathrm{cl}(1989)^{(23)}$ respectively, while syphilis antibodies were determined using indirect hemagglutination technique according to Tomizawa and Kamatsu $(1966)^{(24)}$.

We followed the entire tested groups for the occurrence of abortion, preterm labor or intrauterinc fetal death. Patients who abort were classified into two categories: The first had a titre more than 1/160 and the second had a titer less than 1/160.

All statistical data were expressed according to Cochran (1950) (25) and Montgomery (1991) (26). $P$ value of 0.05 or less was considered significant.

\section{RESULTS}

This study was carried out on 55 pregnant women positive for Brucella antibodies (group 1) and 395 matched pregnant controls (group 2). 
As given in Table I, no statistically significant difference was evident between both test and control groups as regard to age and pregnancy duration.

Antibody titre for Brucella was done in subjects of both groups (G1\&G2) and the percentage of abortion, IUFD and preterm delivery was calculated. As shown in Table II and figurel there were statistically significant differences as regards abortion and IUFD between the test and control groups but no significant difference as regard to preterm labour.

Regarding the results of percentage of abortion, table III lists marked clevation in the percentage of abortion in patients who have a titre more than $1 / 160$ and those with a titre less than 1/160. As given in Table III \& figure 2 there was a statistically significant difference in patients with abortion who have a titre more than $1 / 160$ and those with a titre less than $1 / 160(\mathrm{p}=0.03)$.

\section{DISCUSSION}

Brucellosis is the zoonosis of world wide distribution and common cause of economic loss and ill health among animals and human populations ${ }^{(27)}$.

Brucellosis is an important health problem throughout the Middle East including Egypt. The identification of risk factor patients with acute disease is challenging due to diverse clinical presentations and laboratory tests needed for the diagnosis (28).

Acute febrile illness (AFI) including brucellosis is a very common problem in Egypt . Of 10130 patients evaluated between 1999 and 2003 for acute febrile illness in Egypt, 11\% showed brucellosis (28).

Fallah et al (2005) stated that pneumonia, epididymo-orchitis, human abortion and threatened abortion complicated the disease in patients with brucellosis(12). Maternal infection with brucella during pregnancy can lead to significant perinatal morbidity as abortion, IUFD and preterm labour (29).
Although aggressive public health measures are carried out in the united state, there is a resurgence of interest in this world wide zoonosis because of th potential as a bioweapon and its 8 -folds higher incidences in Calitornia. Texas and the other borderlands between the United States and Mexico compared with the national rate ${ }^{(30)}$.

The high economic loss and public health implications of brucellosis encouraged us to make this study to assess the possible relation between brucella infection and reproductive lailure as expressed by abortion, IUFD and preterm labour.

Our current study showed that the incidence of brucellosis in the study group was $12.2 \%$. This result is in agreement with the study done by Alifi et al (2005) (28) in Egypt and exceeds that of Sherif et al (1990) (31) who reported an incidence of $3.5 \%$.

Our present study showed that the incidence of abortion in pregnant women infected with brucellosis was $27.27 \%$ (table II). Our result exceeds the $10 \%$ rate reported by Crisculo and cli Carlo (29) and that of Sarram et al (32) who observed that among 51 pregnant women infected with brucellosis only 11.0 $\%$ had abortion. But our incidence is less than a $4(1) \%$ rate among 30 pregnant women with brucellosis reported by Madkour (33), and that reported by Lulu et al., ${ }^{(34)}$ who had a rate of $35 \%$ among 35 women who were in the first trimester of pregnancy and had brucellosis and that reported by Khan et al, (20)( ) (35) who reported an incidence of $43 \%$.

This study showed a statistically signilicant difference between group 1 and group 2 as regard to the incidence of abortion ( $p$ value 0.01 ) and IUFD (highly significant $p$ value 0.002 ) and not with preterm labour (table II). This indicates that brucellosis is an important cause of abortion and IUFD. This is in agreement with Malone et al( 1997) (36), Makhseed et al $(1998)^{(37)}$ and Khan et al., $(2001)^{(35)}$. Our results are contrary to that of Seoud et al., $(1991)^{(17)}$ who stated that brucella infection 
has a lesser role in human abortion.

There was a statistically significant difference between the incidence of abortion with titre more than $1 / 160(44.11 \%)$ and that less than $1 / 160(19.4 \%)$ $(P$ value 0.03$)$ and no significant difference as regards to IUFD or preterm labour.

This means that if the titre is higher than $1 / 160$, there is a more liability for occurrence of abortion.

This result was in agreement with that of Sherif et al (1990) (31) who reported that if the titre was higher than $1 / 160$ the incidence of abortion was $17.6 \%$ while the incidence was $7.7 \%$ if the titre was less than $1 / 160$. But our results were contrary to that of khan et al., (2001) (35) who reported that occurrence of abortion was not associated with either the magnitude of the serum agglutinin titre or the presence of brucella bacteraemia.

In conclusion, it is advisable to have a high degree of awareness for brucellosis in pregnant women in rural and city areas. In heavily infected areas a screening program may be in mind. Education in TV programme and news papers for all people about the route of infection, the dangers of contact with infected animals, the dangers of consumption of raw milk and milk products, clinical manifestation and the modes of treatment that should be done.

\section{REFERENCES}

1. Kikuchi H, Kims, Wantonable K, Wataraim: Brucella abortused -alanyl L-D-alanine Caboxypeptidase contributes to its intracellular replication and resistance against nitric oxide. FEMS. Microbial L ctl, (2006): 259(1):120-5.

2. Cardoso PG, Macedo GC, Azcvo V, Oliveiva SC Brucella SPP noncanonial LPS: structure, Biosynthesis and interaction with host immune system. Microb.Cwell .Fact. (2006); 23 (5):13.

3. Xiang $\mathrm{Z}$, Zheng $\mathrm{W}$, He $\mathrm{Y}$ ВBP: Brucella genome annotation with literature mining and Curation BMC Bioinformatics, (2006); 7(1): 347.

4. Alton G. Jones L, Angus R: Techniques for the brucellosis laboratory. INRA, Paris. (1988)
5. Monir madkour M, Dennis L Kaspser. Brucellosis in: Harrison's principle of internal medicine $15^{\mathrm{TH}}$ Edition New York Mc Gerew Hill (2001); 986-9.

6. Ko J, Splitter Molecular host jpathogen interaction in brucellosis: current understanding and Future approaches to vaccine for mice and human Clın. Microbial. Rev, (2003); 16 (1): 65-78.

7. Guitol A, Bossi P, Bricaire F: Bioterroism with brucellosis. Press .Med. (2004); 33 (2):119-22.

8. Wood EE. Brucellosis as a hazard of blood transfusion. Br .Med. J (1995); 1; 27-28.

9. Erten M, Kurekci AE,AysevD,Unal E, Ikinciogullari A brucellosis transmitted by bone marrow Transplantation. Bone marrow transplant (2000): 26:225 -226.

10. Ruben B, Band JD, Wong P, Colville J. Person to person transmission of brucella metilenses LANCET (1991); 337: 14-15.

11.Alsekait MA. Seroepidemiological survey of brucellosis antibodies in Saudi Arabia. Annals of Saudi Medicine (1999); 19: 219-22.

12. Fallah SM, Oduloju AJ ,AL- Dusori SN, Fakunle YM Human brucellosis in northen Saudi Arabia. Saudi Med J. (2005) ; 26(10) 1562-6.

13. Cooper $\mathrm{CW}$. Risk factors in transmission of brucellosis from animals to humans in Saudi Arabla Trans R Soc Trop Med Hyg. (1992); 86: 206-9.

14. Hackmon R, Bar-David J, Bashiri A, Mazor M. Brucellosis in pregnancy. Harefuah. (1998) Jul; 135 (1-2); 3-7, 88 .

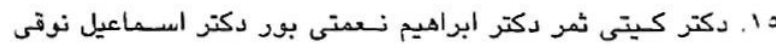

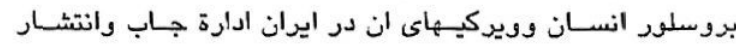

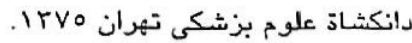

16. Poole PM, White house DB, Gilchrist MM. A case of abortion consequent upon infection with Brucella abortus biotype 2. J Clin Pathol (1972): 25: 882-4.

17. Scoud M, Saade G, Awar G, Uwaydah M. Brucellosis in pregnancy. $J$ reprods Med (1991); 36: 441-5.

18. Freter R (1980) man. of clin .imm. $2^{\text {nd }}$ edition A. S. M.Washington DC 460-453.

19. Young EJ, Brucella species. In mandall Gl, Benett JE, Dolin R. principles and practice in Infectious diseases. Fifth edition. Churchill Livingstone. New York (2000); 2386 -2393.

20. Wisclom GBC (1976); Enzyme immunoassay, Clin, Chem... 22:1243.

21. Engvall E and Perlmann P: J immunochemistry (1971); 8: 871-874. 
22. Verneri $A$ and Salonen E: Evaluation of solid phase cnzyme immunoassay procedure in Immunity surveys and diagnosis of rubella A. J Med. Virol. S (1980); 171-180.

23. Alter H. Koo G, Choo G: An assaly for circulating antibodies to major etiologic viruses of Human non A non B hepalitis. SCIENCE (1989); 244: 362-4.

24. Tomizawa T. Kamatsu S. med. sci-biol (1960); 19-30.

25. Cochran WG: The comparison of percentages in matched samples. Bionetria; (1950); 37: 256-266.

26. Montgomery D: Design and analysis of experiments. New York 3RD edition (1991); p 163.

27. Baba MM. Sarkindared SA, Brisibe F.; Serological evidence of brucellosis among Predisposed patients with pyrexin of unknown origin in the north eastern Nigeria: cen Eur J Public health; (2001); Aug; 9 (3); 158-61.

28) Afifi S, Ealthart K, AzabMA et all. Hospital -based surveillance for acute febrile illness in Egypt: a Focus on community jacquired blood stean inlections. Am J Trop Med Hyg (2005); Aug; 73 (2): $392-9$.

29. Crisculo E, di Carlo FC . Elaborto ostras manifestations ginccobststricas en el curso de la brucellosis humanal. Rev Fac Cien Med Univ Nac Cordoha (1954); 12;321-30.
30. Troy SB, Rickman LS, Davis CE.brucellosis in San Diego: Epidemiology and species -related differenees in acute clinical presentations; Mudicine (Baltimore). (2005) may; 84(3) 174-87.

31. Sherif A, Reyes $Z$, Thomassen $P$ Screning for brucellosis in pregnant women. J. Trop. Med. Hyg (1990) Feb: $93(1): 42-3$.

32. Saram M. Feizf, ForuzanfarpourP lntraulertic ictal infection with brucella meltensis as a ponshit. Cause of second itrimester abortuon. Am J Ohstet Gynacol (1974); 1 19:657-60.

33. Madkour MM, Pregnancy and brucellosis. In Madkour MM ed. Brucellosis. London: B Utterworth, (1989); $197-204$.

34. Lulu AR, Araj GF, Khateeb MI, Mustala MY. Yusuf AR, French FF human brucellosis in kuwil: : Prospective study of 400 cases. Q J Med (1988): 66 . 39-54.

35. Khan MY. Mab MW. Memish ZA. Brucell pregnam women. Clin inlect Dis. (2001) Apr 15; 32 (S): 1 172-7.

36. Matone FD, Athanassiou A, Nores LA, Daltom ME. Poor perinatal outcome associated with Maternal Brucellat abortus infection. Obstet gynaco: (1047) Oc1: 90 (4PT2): $674-6$.

37. Makliseed M.Harouny A,Araj G,Mouissal MA it all obstctric and gynecologic implication of Brucedlosis in kuwit J Perinatol (1998); 18: $196-9$.

Table I : Age and pregnancy duration in the two groups .

\begin{tabular}{|l|c|c|c|}
\hline \multicolumn{1}{|c|}{ Group } & $\begin{array}{c}\text { Group 1 } \\
(\mathrm{n}=55)\end{array}$ & $\begin{array}{c}\text { Group 2 } \\
(\mathrm{n}=395)\end{array}$ & P value \\
\hline Age (years & $27 \pm 6$ & $26 \pm 8$ & 0.2 \\
\hline Pregnancy duration (weeks) & $9 \pm 2$ & $8 \pm 6$ & 0.1 \\
\hline
\end{tabular}

There wats on statistically signilicant difference between both tested groups

Table II : Number and percentage of abortion, IUFD and preterm labour of the two studied groups .

\begin{tabular}{|l|c|c|c|}
\hline \multicolumn{1}{|c|}{ Group } & $\begin{array}{c}\text { Group I } \\
(\mathrm{n}=55)\end{array}$ & $\begin{array}{c}\text { Group 2 } \\
(\mathrm{n}=395)\end{array}$ & P value \\
\hline Abortion & $15(27.27 \%)$ & $(10(1.5 .15 \%)$ & 0.01 \\
\hline IUFD & $7(12.72 \%)$ & $15(3.79 \%)$ & 0.0612 \\
\hline Preterm lithuur & $6(10.90 \%)$ & $35(8.86 .5)$ & 0.3 \\
\hline
\end{tabular}


Table III : The relation of the percentage of abortion, IUFD and preterm labour to the titre of brucellosis.

\begin{tabular}{|l|c|c|c|}
\hline \multicolumn{1}{|c|}{ Group } & $\begin{array}{c}\text { Titre More the } \mathbf{1} / \mathbf{1 6 0} \\
(\mathbf{n}=\mathbf{3 4})(\mathbf{G a})\end{array}$ & $\begin{array}{c}\text { Titre Less than 1/160 } \\
(\mathbf{n = 2 1})(\mathbf{G b})\end{array}$ & P value \\
\hline Abortion & $15(44.11 \%)$ & $4(19.4 \%)$ & P value \\
IFUD & $2(20.58 \%)$ & $4(19.4 \%)$ & \\
Preterm labour & $6(17.64 \%)$ & $7(33.33 \%)$ & \\
\hline
\end{tabular}

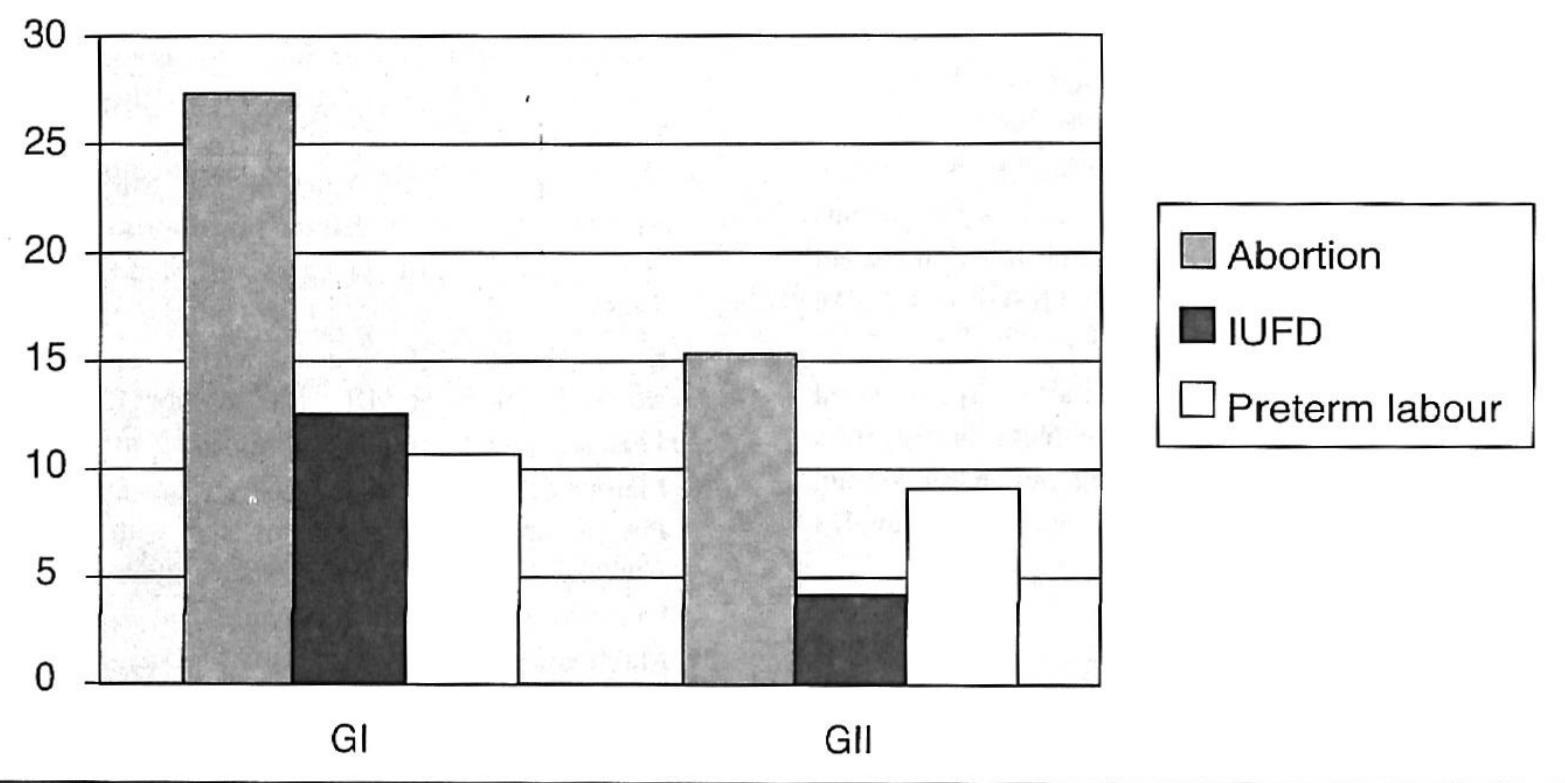

Figure 1 : Percentage of abortion, IUFD and preterm labour in the two studied groups.

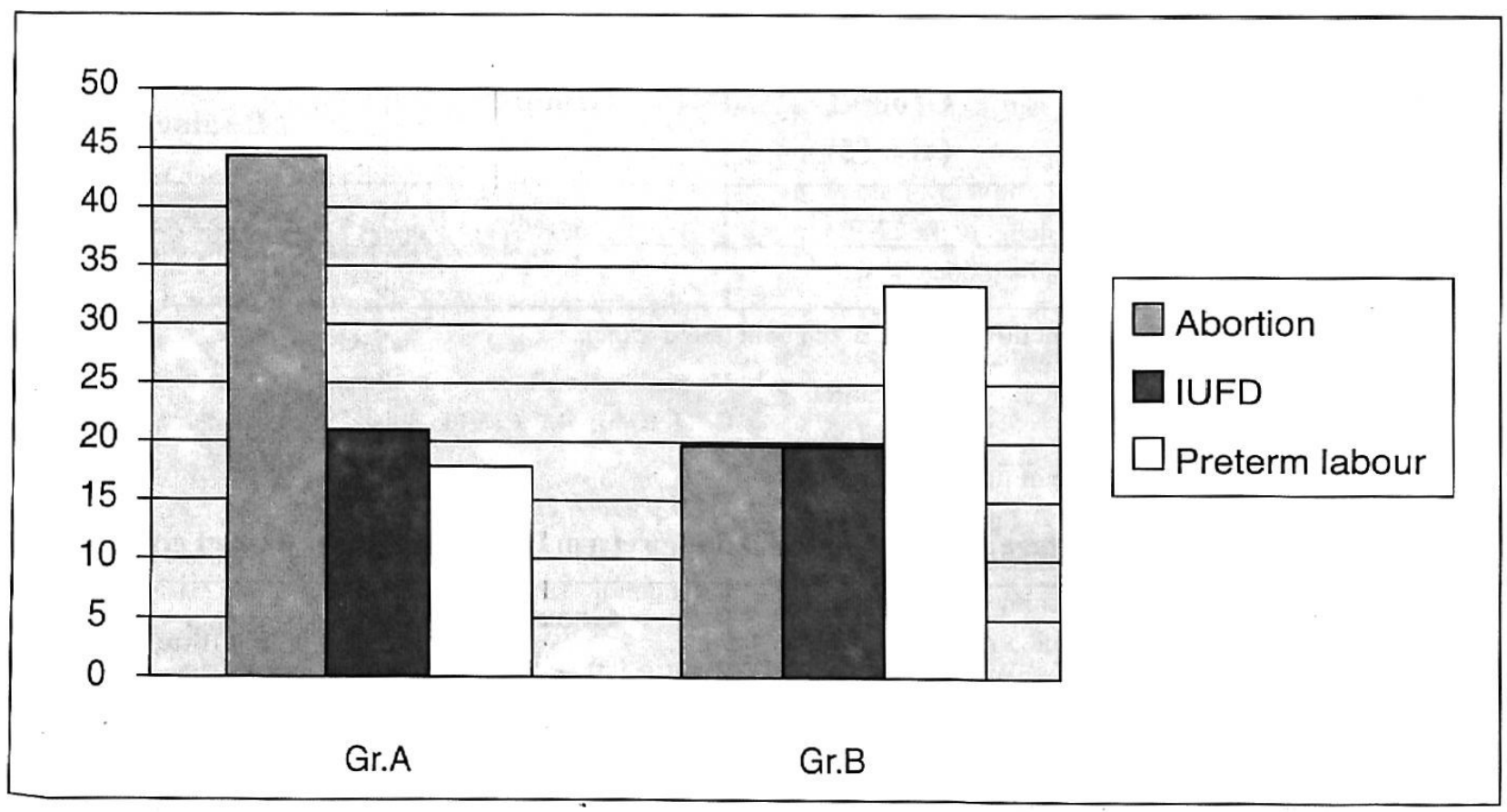

Figure 2 : The relation between abortion, IUFD and preterm labour and the titre of brucellosis 